$63^{\text {ème }}$ Congrès de la SFCO, 03019 (2015)

DOI:10.1051/sfco/20156303019

(C) Owned by the authors, published by EDP Sciences, 2015

\title{
Chirurgien ORL et Oral : double équipe pour le traitement chirurgical des sinusites chroniques
}

\author{
Decréquy M*, Butel A*, Louvet B*, Di Bernardo G*, Lacheretz C*, Nawrocki L*, \\ Mortuaire $\mathrm{G}^{* *}$, Chevalier $\mathrm{D}^{* *}$, Langlois JML* \\ * Service d'Odontologie du CHRU de Lille, Université de Lille \\ ** Service d'ORL du CHRU de Lille, Université de Lille
}

The Caldwell-Luc Surgery « CLS » (enlarged canina fossa opening to access to the maxillary antrum) was first described in the United States by George Walter Caldwell in 1893 and then by Henri Luc from France in 1897. For a long time it has been the reference surgery in removal dental sinus root projection or to cure sinus affected by chronic sinusitis (aspergillosis, ...) until the advent of Functional Endoscopic Sinus Surgery «FESS » optimized by medical treatment. Moreover CLS is responsible for many sequelae as reported in the literature (neuralgia...). Howewer, CLS is still used today with a minimal approach using an endoscopic device. This surgery has been supported for many years (simultaneous to a middle meatus antrostomy) by the Ear.Nose.Throat "ENT» and Oral Surgeons of the Regional University Hospital of Lille (France), specially for aspergillosis or in failure of only FESS technique. The aim of this poster is to illustrate the modified CLS technic used in ENT service of the Regional University Hospital of Lille with a double surgical gesture (ENT/Oral surgeons).

La technique chirurgicale de Caldwell-Luc (accès au sinus maxillaire par trépanation osseuse au niveau de la fosse canine) a été décrite pour la première fois aux Etats-Unis par George Walter Caldwell en 1893 et par Henri Luc en France en 1897. Cet abord a longtemps été la chirurgie référencée pour récupérer les projections de racine dentaire dans le sinus maxillaire ou pour soigner des sinusites chroniques (aspergillaire) et ce jusqu'à l'arrivée des techniques chirurgicales sinusiennes endoscopiques fonctionnelles optimisées par des traitements médicaux. De plus, la technique de Caldwell-Luc est à l'origine de nombreuses séquelles relatées dans la littérature (névralgie). Cependant, l'abord de Caldwell-Luc est toujours utilisé de nos jours mais l'ouverture est minimaliste permettant l'usage de matériel endoscopique ; cette technique opératoire modifiée est pratiquée depuis plusieurs années (en complément d'une méatotomie moyenne) par l'équipe de chirurgiens (ORL et Oral) du CHRU de Lille (France), spécialement dans le traitement des aspergilloses ou en cas d'échec des techniques endo-nasales seules. Le but de cette communication affichée est d'illustrer cette technique de Caldwell-Luc modifiée pratiquée au sein du service d'ORL du CHRU de Lille en double équipe (Chirurgiens ORL et Oral).

Chemil \& al. 2012 ; Sinusites maxillaires d'origine dentaire : traitement chirurgical. Rev Stomatol Chir Maxillofac. Volume 13, $\mathrm{N}^{\circ}$ 2, pages 87-90

Chobillon \& al. 2004; What are the advantages of the endoscopic canine fossa approach in treating maxillary sinus aspergillomas? Rhinology, 42:230-5

Costa \& al. 2007; Surgical treatment of aspergillus mycetomas of the maxillary sinus: review of the literature. Oral Surg Med Oral Pathol Oral Radiol Endod. 103(6):e23-9

This is an Open Access article distributed under the terms of the Creative Commons Attribution License 4.0, which permits unrestricted use, distribution, and reproduction in any medium, provided the original work is properly cited. 
Facon \& al. 2005 ; Chirurgie endonasale micro-invasive : apport de l'endoscopie en chirurgie maxillofaciale. Rev Stomatol Chir Maxillofac. Vol 106, N 4, pp. 230-242

Gibb \& al. 1938; Persistant suppuration of right maxillary antrum after a caldwell-luc Operation. Proc R soc Med; 31(6):660

Pentilla \& al. 1994; Endoscopic versus Caldwell-Luc approach in chronic maxillary sinusitis: comparaison of symptoms at one-year follow up. Rhinology, 32, pp.161-165

Nom et adresse du conférencier

Marcel DECREQUY

Faculté de Chirurgie Dentaire

1 place de Verdun CHRU Lille

59000 Lille (France)

decrequymarcel@yahoo.fr 